\title{
Avaliação Sensorial e Microbiológica de Biscoito Elaborado com Substituição Parcial de Farinha de Trigo por Farinha de Arroz e de Linhaça
}

\author{
Endy Camile de Noronha (I), Mônica Turchetto (I), Pablo Teixeira da \\ Silva (I), Ana Eucares Von Laer (I) \\ (I) UFSM - Universidade Federal de Santa Maria (Linha Sete de Setembro, s/n, CEP: 98400- \\ 000, Frederico Westphalen, RS, Brasil)
}

\section{Resumo}

O Biscoito está entre os produtos mais populares em todos os níveis da sociedade, por ser de boa qualidade nutricional, ter diversas variedades e ser de custo acessível. Este produto revela-se um bom veículo para o estudo de farinhas mistas, seja por razões econômicas ou nutricionais. Portanto, o presente trabalho foi realizado com objetivo de desenvolver um biscoito com base na substituição parcial de farinha de trigo por farinhas de arroz e a de linhaça, para enriquecimento nutricional, determinando sua aceitabilidade através de testes sensoriais e sua qualidade microbiológica. Para obtenção das quatro formulações de biscoito, com diferentes concentrações de farinha de arroz, 15,25 e $35 \%$, e $10 \%$ de farinha de linhaça, além de um biscoito padrão, os ingredientes secos foram homogeneizados e a massa foi sovada manualmente. Posteriormente, a massa foi dividida em porções de aproximadamente 15 a 16g, moldadas em formato circular. Os biscoitos foram assados, resfriados em temperatura ambiente e acondicionados sob atmosfera comum em sacos plásticos. Nas amostras obtidas, foi realizada análise sensorial de aceitabilidade (cor, sabor, odor, aparência, textura e avaliação global), utilizando escala hedônica de nove pontos; intenção de compra utilizando escala hedônica de cinco pontos; e teste de ordenação, para avaliar a preferência sobre atributo sabor das amostras, ambos os testes com a participação de cinquenta julgadores não treinados. Também foram realizados testes microbiológicos

\footnotetext{
Referência:

Endy Camile de Noronha, Mônica Turchetto, Pablo Teixeira da Silva, Ana Eucares Von Laer. Avaliação Sensorial e Microbiológica de Biscoito Elaborado com Substituição Parcial de Farinha de Trigo por Farinha de Arroz e de Linhaça. In: Anais do 12 Congresso Latinoamericano de Microbiologia e Higiene de Alimentos - MICROAL 2014 [= Blucher Food Science Proceedings, num.1, vol.1]. São Paulo: Editora Blucher, 2014. 
para contagem de Staphylococcus aureus, bolores e leveduras e presença de coliformes totais. Todas as formulações obtiveram boa aceitação, com viabilidade de produção maior para as formulações com maior concentração de farinha de arroz. Não houve presença de Staphylococcus aureus nem de coliformes totais nos biscoitos, e para bolores e leveduras os resultados de todas as amostras ficaram dentro dos padrões de identidade e qualidade. Os testes sensoriais indicaram que além de enriquecer nutricionalmente o biscoito, as farinhas melhoraram sensorialmente o produto, e os testes microbiológicos apontam para um alimento seguro ao consumo humano, portanto se revelou um produto com ótima viabilidade de produção e comercialização.

Palavras-Chave: aceitabilidade, qualidade, farinhas mistas Agência de Fomento: 